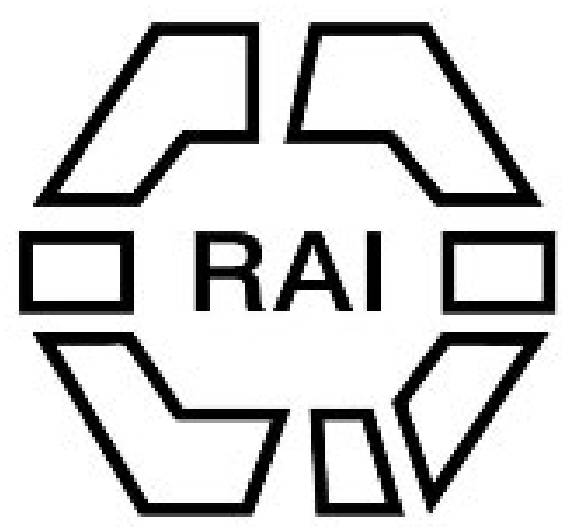

Notes in Connection with Stone Implements from Natal.

Author(s): John Sanderson

Source: The Journal of the Anthropological Institute of Great Britain and Ireland, Vol. 8 (1879), pp. 15-21

Published by: Royal Anthropological Institute of Great Britain and Ireland

Stable URL: http://www.jstor.org/stable/2841186

Accessed: 15/06/2014 08:53

Your use of the JSTOR archive indicates your acceptance of the Terms \& Conditions of Use, available at http://www.jstor.org/page/info/about/policies/terms.jsp

JSTOR is a not-for-profit service that helps scholars, researchers, and students discover, use, and build upon a wide range of content in a trusted digital archive. We use information technology and tools to increase productivity and facilitate new forms of scholarship. For more information about JSTOR, please contact support@jstor.org. 
From the EdroR.- "Nature" (to date).

From the Editor.-Revue Scientifique, Nos. 33-34, 1878.

From the Editors.-Bulletino di Paletnologia Italiana, No. 12, 1877.

Mr. John SANDERson exhibited some stone implements from Natal, and communicated the following paper relative to the same.

\section{Notes in Connection with Stone Implements from Natal.}

\section{By John Sanderson, Durban, Natal.}

Having, on the invitation of your President, the privilege of exhibiting a few stone implements, perhaps the first which have been shown in this country in any number, from the Colony of Natal, it may be of interest that I should say a few words on the subject of the present native inhabitants and give you the impressions I have formed as to the probability of their being the descendants of the men who made the implements now before you. I shall have but little to say on the implements themselves, beyond this, that they have all been found by myself within the last few months, and in, or in the vicinity of, the town of Durban.

The country now known as Natal was discovered, as most present are probably aware, by Vasco di Gama on Christmas Day, 1498. The accounts of the early Portuguese visitors which have fallen in my way are very meagre, being simply such as are given in Mr. Major's "Life of Prince Henry." I gather from these however that the inhabitants of the present Colony of Natal were at the date named not of the Kafir race, but more probably of the Hottentot or Bushman family, the "black men" being first met with on the east coast of South Africa to the North of Delagoa Bay.

There is therefore historical reason to believe that whatever race may have left traces of its existence in Natal in the form of these stone implements, they did not belong to the Kafir family, unless indeed that family after occupying the country in very remote ages, had been driven out to return only within the last, 300 or 400 years. Dutch records of about 200 years back give the names of many Kafir tribes occupying approximately the same positions as they do now, among them being the Amakosa Amatembu, Amampondo, Amagcaleka and others, so that the intrusion of the great Kafir family into the countries from Delagoa Bay to the present limits within the Cape Colony may approximately be said to have taken place in the sixteenth and seventeenth centuries, while it is beyond a doubt that the 
greater part of these stone implements are of much earlier date, having been found at such a depth and in such positions as probably to indicate that a very long series of years has passed since they were deposited where found. If this view be correct, therefore, it would be rash to conclude that the implements are the workmanship of the ancestors of the present Kafir inhabitants of the country.

At the same time there are two facts to which I wish to direct attention; one is that certain implements of stone are still in use among the native races, among which are perforated balls employed to give weight to digging sticks, and stone hammers still used by native blacksmiths in remote parts of the country, not to speak of the hollow stones with mullers used for grinding tobacco, etc. I have also obtained from the Zulu country, and some years ago sent home, a couple of stone crucibles used for smelting metals, probably copper or possibly silver, the latter metal, however, being no longer in use among them, and among the specimens before you is a small globular crucible which I imagine to have been used for smelting gold, though found 150 miles from any known gold-field.

The other fact to which I have alluded is this, that native literature, small as the amount of it yet published is, contains more than one allusion to stone being employed for cutting purposes. Thus in the Zulu tale of Usitungusobenhle, the heroine being pursued by the Amajubatente, gets rid of them by casting a rope under pretence of helping them across a river or strait, and cutting it with a sharp stone. And in a specimen sheet of the "Tales of the Ama-Xosa" which the Rev. Mr. Shea proposes, should he get adequate support, to publish, one of the characters addresses another in these words :- "With this sharp stone I will cut off your head." (Theal, p. 14).

Dr. Callaway's "Traditions of the Zulus," to which I have already referred, contain here and there, I think, traces of an earlier race as well as of usages now no longer practised and to which I may be allowed briefly to refer. Just as Campbell and other writers believe the references to fairies or goblins in West Highland stories in reality to be traditions of a Lap race antecedent to the present Celtic inhabitants, so I am disposed to think, that the cannibals which figure in the tale of Uhlakanyana and others, and which are constantly spoken of as "long haired," belonged to another race of men.

"The long-haired cannibal," " as long-haired as a cannibal," are expressions constantly recurring in these tales; and Uhlakanyana pretending to help the cannibal to thatch his house, takes the opportunity of sewing his long hair in with the thatch and then leaves him to perish. These references seem to me to point to 
some straight or lank-haired race of men as distinguished from the crisp or woolly-haired Zulu who tells the tale.

These cannibals, whatever race they may have belonged to, are first cousins to our own Blunderbores, whom Jack the Giantkiller had to encounter.

They are represented as stupid, so stupid as to allow themselves to be starved while the hero and heroine are feasting before their faces. They surpass "men" in running, but are skilful in nothing else. They are " no longer men;" they neither live in houses nor cultivate the soil, nor do they possess cattle or sheep. In a word, like the ogres and giants of our own nursery tales, they are represented as great lumbering man-eating louts, but so wanting in intelligence as to be deluded by a child.

As I have already hinted, the Zulus and Natal Kafirs are, and for some generations have been, workers of iron; their spears (usually called assegais by the whites) being of various. form and size, being employed for cutting skins, dividing meat, carving wood, and for a variety of other purposes, besides being used in war and the chase. But in the Zulu tales I have observed at least two references to the rind of the wifi or sugar reed being used as a knife or lancet, exactly as the bamboo is still used in the South Sea Islands. This primitive implement has long been superseded by iron knives of native manufacture, from the ore which abounds in' the present country of the Zulus, but mav have been unknown in the northern region from whence they came, or which they occupied when the tale took its rise.

In the tale of Usitungusobenhle the King puts a number of girls to death by beheading them on a block, a mode of execution not now practised among the Zulus.

This act of justice is said to have been performed with a sword; but swords, in our sense of the word, are not used by the Kafirs, and if some weapon now no longer employed by them is not intended, a spear or assegai made larger and heavier than usual is probably meant.

The comparatively great value of an iron spear, when metal began to supersede earlier materials, may be gathered from the tale of Uhlakanyana, who by a series of manœuvres similar to those of Grimm's "Clever Countryman" and the heroes of Gaelic, Norse and Ananzi stories, gains at last a war spear in lieu of a mess of edible roots. The rarity of iron may be inferred from the superstitious dread of it attributed to the long-haired cannibal race in another tale, where the sister says to her brother, "Since you have a spear he will be afraid to eat us; for cannibals are afraid of a spear:" (Callaway, p. 148).

Among practices which may formerly have been in use among the Kafirs or the Zulu branch of them, b'it are now unknown, vot. VIII. 
or the knowledge of which may have been traditionally derived from some earlier race, is that of cooking by means of hot stones, still in use among savage peoples in many parts of the world, and of which we read in Dr. Callaway's Zulu tale of Usikulumi, (p. 42).

Again; excepting one or two tribes driven to eat fish by the famine in the time of Tshaka's wars, no Zulu or Natal Kafir now eats a creature regarded as a kind of snake. But in the story of Isitshakamana, a man goes to catch fish by means of a worm as a bait. The hook is not mentioned, but may fairly be inferred. The present mode of catching fish among these Kafir tribes who use them, is by means of wattled kraals or enclosures which the fish enter at high water and cannot leave when the tide recedes. Baskets like lobster pots are also used.

In several of the Zulu tales the bride is described as wearing a veil, sometimes so transparent, we are told, that if any one put it on, the body could be seen. (Umkxakaza, Callaway, p. 201.) No such article of attire is in use among the Zulu Kafirs nor have they any fabric which could be employed for such a purpose. They neither weave any kind of fibre, nor prepare barkcloth, as the natives do only a few hundred miles further north. The word used for a veil signifies a spider's web, and the name so applied and the traditions in the tale, probably refer to a time when the Kafirs still occupied a country where trees grew which would lend themselves to such a purpose, as is the case on the Kilimane coast; or where cotton or other fibres were woven into cloth, as is also the case further north. Or, what is less likely, the story and the notion of a veil may both be borrowed from some other race.

The native huts or houses of the Zulus are semi-globular in form, made of sticks or neatly thatched over; but in one tale ("Ugungqu-Kubantwana," p. 173), we read of a house so "long" that it was dark inside at the further end.

I shall only refer to one more example, and that not the least interesting, of a practice not now in use among the Zulus, but of which their literature gives us knowledge. In the tale of Umkatshana we are told that when a man dies in this world and has gone to the people who live beneath, they say to him, "Do not come near us at once; you still smell of fire." They say to him, "just remain at a distance from us, until the smell of the fire has passed off." (Callaway, 318.) This evidently implies that burning of the dead was formerly in use although not now practised. And accordingly in Dr. Callaway's later but uncompleted work, the "Religious System of the Amagulu," p. 213, we read that, " at first the bodies of the dead were burnt." But the extract gives us also evidence of a belief in an existence 
beyond the grave. This, however, is neither the time nor place to pursue the inquiry.

My object in referring to these points at all is to show that the tales current at the present day among the Kafirs contain by no means indistinct traces of some race preceding their own, or at least of a different stage of civilization, and one or two of which are even directly connected with the stone age or ages.

The first mention of stone implements being met with in Natal that I am acquainted with in print is that which occurs in a note on Griesbach's paper on the "Geology of Natal," (Proceedings Geol. Soc. Quarterly Journal, 1871, p. 69), in these words:-The writer has seen implements of early man which were obtained by Richard Thornton and others in old raised beaches at Natal, near Juanda, and at the mouth of the Zambesi River. Mr. Griesbach visited Natal, if I remember rightly, in 1870, but I happen to know that years before, your President had urged relatives in the colony to search for stone implements in the full assurance that they would be found. I had also for a good many years been aware that they had been found near the Umhloti River but had failed to procure any specimens, except of stone hammers such as are still in use for smithy work. It was not until September 1876 that I found my first specimen; and on the commencement of the government railways, I begged Mr. W. D. Gooch, who had charge of the works on the short North Coast Line and had an extensive acquaintance with stone implements in Copenhagen and other museums, and had besides collected them in Southern Russia and elsewhere to use his opportunities to search for them. Mr Gooch speedily made a considerable collection, and having seen these and accompanied him once or twice in search of specimens, I set to work in other localities around Durban.

With the single exception of fragments of polished stone rings, all that $I$ have found and indeed seen, are exceedingly rude. But when I consider the very limited area of country yet examined, and that only in a few lines of road or railway, I am amazed at their numbers, indicating the whole country to be covered with them. I may mention that among those exhibited are a few fragments of petrified wood from the Free State. In the account of a trip into the Free State and Transvaal which I made in 1851 and 1852, which appeared in the Proceedings of the Royal Geographical Society, I have referred to the profusion with which fragments of this material occurred among black clay along the beds of intermittent streams between the False and the Renoster Rivers. The immense numbers, their small size and un-water-worn condition greatly puzzled me at the time. 
But on re-examining such specimens as I still had by me, I found three or four apparently worked by human hands, and I should therefore be inclined to conclude that $I$ had fallen in with a manufactory of implements. The specimens are among these exhibited.

I shall conclude these desultory remarks by reading some extracts from a few notes prepared by $\mathrm{Mr}$. Gooch to accompany some specimens exhibited by him in Durban.

Mr. Gooch begins by speaking of the materials of which the stone implements found by him consist. He says :-

"Materials.-The classes of stone used in Natal range from hard shale, through the different hard grits to the trap rocks, up to quartz and chalcedony.

"Age.-As a rule, however, the less adapted the class of stone to the use required of it, the greater may the age of the deposit in which it is found, be expected to prove itself. For instance, superficial drift sand and late river marls give better specimens, than the deep-lying marl of the coast and the lateritic formations throughout the colony.

"Deposits. - The latter formations throughout Natal, at from one foot to four feet below the surface, are nearly always rich in these implements, and the implements seem to be pretty evenly dispersed during that period. Since that deposit, however, there seems to have been some cause operating preventing the deposit of any weapons except very locally; but then they occur somewhat abundantly. These implements, when so found, are of a more advanced type, and if in drift sand are often worked stone and belong to the Neolithic types of other parts of the world. We can then separate the groups into Palæolithic and Neolithic; the Neolithic being confined to the drifted sand above referred to and similar deposits, and the Palæolithic embracing those of the Laterite, Nodular Lime and Marly deposits throughout the colony.

"Locality.-The stone implements have been obtained everywhere in excavations, from the Red Hill to the Great Umhlanga in Victoria County, and also at Pinetown, Thornville, Maritzburg, and at Estcourt, in Weenen County. As this is the result of a very cursory inspection of the colony, it may be supposed that they are to be found nearly everywhere.

"Types.-The most usual types are :-

(1) Knives for cutting skins, \&c.

(2) Scrapers for preparing skins.

(3) Piercers for drilling holes; generally of quartz.

(4) Moulding tools, for making pottery, \&c.

(5) Chisels for cutting wood, \&c. 
(6) Spear heads 7 (7) Arrow-heads, large $\}$ Weapons for offence and the chase."

(8) Do. small

The President and Canon Greenwell offered some remarks.

The following paper was read by the Author:-

\section{The Pre-Historic Civilisation of Babylonia, by W. St. Chad Boscawen, Esq.}

In my lecture this evening it is my intention to endeavour to lay before my hearer's some of the chief facts to be gained from the Cuneiform inscriptions respecting the early civilisation of the land of Babylonia.

Tradition has marked out certain spots, on the surface of the earth, as centres from whence radiated the civilisations of certain ethnic groups of the human race. With the exception of Egypt, none can rival the one which forms the subject of my lecture, in antiquity or in the rich traditions which mark it out as a field for anthropological research.

Somewhat over half a century has elapsed since the mathematical genius of Young and the perseverance of Champollion forced the Kabala of Egyptology to yield its secrets, and open the treasure house of buried Egypt. Since the day when the two names Ptolemy and Cleopatra became the "open sesame" of the Egyptian cave of Ali Baba, how many hundreds of inscriptions, and thousands of beautifully written papyri, have yielded up their secrets to the patient labour and research of such men as Birch, Lepsius, Renouf, Chabas, and others. Seeing how that in half a century of research and study we have the main vertebræ of Egypt's story before us, we turn to her annals to solve the problem of her pre-historic patriarchs.

But in this very point the hieroglyphic writing yields us but scant information. In the inscriptions of the earliest of her dynasties we find a fully developed language, a rich and carefully composed phonetic system, and a literature regulated and governed by grammatical laws; in fact, every indication of centuries of philological development. We all know that the growth of a language is not the work of days or years, but of centuries and millenia. On turning to Egypt's most primitive jecords, we find her far advanced in the scale of civilisation; so high is the linguistic advance at the period of the VIth and early dynasties, that there are only dialect differences between 